\title{
Oxygen reduction activity and methanol tolerance of carbon-supported PtV nanoparticles and the effects of heat treatment at low temperatures
}

\author{
R. Gentil ${ }^{1}$ - H. M. Villullas ${ }^{1}$
}

Received: 5 May 2015 /Revised: 29 June 2015 / Accepted: 1 July 2015 /Published online: 11 July 2015

(C) Springer-Verlag Berlin Heidelberg 2015

\begin{abstract}
This paper reports on oxygen reduction activity and methanol tolerance of $\mathrm{PtV} / \mathrm{C}$ prepared by a polyol method and the effects of heat treatments in reducing environments at low temperatures (up to $300{ }^{\circ} \mathrm{C}$ ). The as-prepared catalyst showed a low content of alloyed vanadium, but it was considerably more active for the oxygen reduction reaction than $\mathrm{Pt} / \mathrm{C}$ and had superior methanol tolerance. Dispersive X-ray absorption spectroscopy measurements around the $\mathrm{Pt} \mathrm{L}_{3}$ edge indicated that the presence of vanadium in the catalyst increased the Pt 5d-band vacancy at the time that it seems to diminish the $\mathrm{Pt}$ coverage by adsorbed $\mathrm{OH}$ species. Heat treatments at 150,200 , and $300{ }^{\circ} \mathrm{C}$ carried out in strongly reducing conditions produced minor changes in the degree of alloying together with a moderate particle growth. The largest incorporation of vanadium in the alloyed phase was observed after heating at $150^{\circ} \mathrm{C}$ while a decrease in the alloying and Pt segregation to the surface were observed for higher treatment temperatures. In general, heat treatments were detrimental for oxygen reduction activity, suggesting that the presence of vanadium oxides might play a role. In addition, the decreased in methanol tolerance might be associated to Pt segregation to the surface.
\end{abstract}

Keywords Oxygen reduction · Pt-based catalyst · Pt alloys · Methanol tolerance

H. M. Villullas

mercedes@iq.unesp.br

1 Instituto de Química, Univ. Estadual Paulista - UNESP, Rua Francisco Degni 55, Araraquara 14800-900, SP, Brazil

\section{Introduction}

Proton exchange membrane fuel cells (PEMFC) and direct alcohol fuel cells (DAFCs) are devices that convert chemical energy into electricity that are suitable for vehicle and portable applications [1]. Nonetheless, improvements of performance are yet essential to make the generation of electrical power from fuel cell systems more efficient and affordable. Among them, more efficient cathode catalysts are necessary to overcome the substantial overpotential losses associated to the sluggish kinetics of the oxygen reduction reaction (ORR). Towards that end, a great deal of research was carried out over the past decades involving Pt-based materials as well as Ptfree catalysts [2]. However, because Pt-free materials do not have high activities and, in many cases, lack stability [3], Ptbased catalysts still are the catalysts of choice for cathodes of PEMFCs and DAFCs.

A large number of studies of ORR was conducted on carbon-supported binary catalysts that combined Pt with $3 \mathrm{~d}$ transition metals, such as PtNi [4-6], PtCo [6-8], PtFe [6, 9, 10], and $\mathrm{PtCu}$ [11-13]. In most cases, these Pt-based materials exhibited larger activities for the ORR than pure $\mathrm{Pt}$ [14], which has been interpreted in terms of more favorable Pt-Pt nearest-neighbor distance [15], changes in the Pt 5dband occupancy [16] and of a decrease in $\mathrm{OH}$ coverage promoted by the second metal [16] or by transition metal oxides [17]. In addition, the ORR activity of Pt-based catalysts depends on the second metal chosen [18] and might be significantly influenced by properties such as nanoparticle shape, composition, etc. [19]. Besides the numerous studies of the ORR that were performed on carbon-supported Ptbased catalysts, significant contributions towards the understanding of fundamental aspects of ORR electrocatalysis came from studies carried out on model systems such as extended alloys [20]. Other contributions came from 
theoretical approaches. For instance, density functional theory calculations made for $\operatorname{Pt}(111)$ suggested that the origin of the overpotential for Pt might be related to the stability of adsorbed oxygen at high potentials [21].

Many Pt-based bimetallic catalysts are also better that pure Pt regarding alcohol tolerance [22]. This latter property is particularly relevant in the case of direct methanol fuel cells (DMFCs) where the crossover of the alcohol through the polymer electrolyte to the cathode compartment is still one major problem. Because the cathode potential is high, the oxidation of methanol taking place simultaneously with the ORR causes a mixed potential that severely affects the cell performance.

Pt-based bimetallic catalysts containing more difficult to reduce and more oxophilic early $3 \mathrm{~d}$ transition metals were studied to a much lesser extent. The amount of published papers reporting the preparation of carbon-supported $\mathrm{PtCr}$ for ORR electrocatalysis is relatively modest [23, 5, 24-26, 6,27], while the incorporation of $\mathrm{Cr}$ into the Pt lattice forming an alloyed phase seems to be the exception rather than the rule and its effects are still controversial [28]. An even lower number of studies of ORR involved PtV catalysts [29, 26, 30, 6]. Catalysts for ORR have been often heat treated at high temperatures $\left(>500{ }^{\circ} \mathrm{C}\right)$ in reducing atmosphere (pure or dilute $\mathrm{H}_{2}$ ) to promote alloy formation, with the disadvantage of producing also substantial particle growth [31].

Even though studies of PtV catalysts are rather scarce, published data indicate that ORR activities are larger than for $\mathrm{Pt} /$ C. The activity of commercial PtV/C catalysts for ORR was evaluated for as-received and heat-treated samples in $\mathrm{H}_{2} \mathrm{SO}_{4}$ [29] and $\mathrm{KOH}$ [26] solutions as well as in PEM fuel cells [30]. To the best of our knowledge, ORR studies on noncommercial $\mathrm{PtV}$ catalysts were only done in $0.1 \mathrm{~mol} \mathrm{~L}^{-1}$ $\mathrm{HClO}_{4}[6]$ and in $\mathrm{H}_{3} \mathrm{PO}_{4}$ solutions [32, 33].

In this paper, we studied the catalytic activity towards the ORR of as-prepared PtV/C synthesized by a polyol method as well as the effects of heat treatments at low temperatures on ORR catalytic activity and methanol tolerance.

\section{Experimental details}

For the synthesis of the catalysts, colloidal PtV nanoparticles of nominal atomic compositions Pt:V 1:1 (in atoms) were first obtained in dioctyl ether by a polyol method [34], with some minor modifications [35]. Concisely, the metal precursors (acetylacetonates) and the reducer (1,2 hexadecanediol) were dissolved in dioctyl ether and the solution was then heated under Ar atmosphere. Capping agents (oleic acid and oleylamine) were added to the mixture at $110{ }^{\circ} \mathrm{C}$, and then heating was maintained until reaching the temperature of reflux $\left(298^{\circ} \mathrm{C}\right)$ that was kept for $30 \mathrm{~min}$. After that, heating was stopped and the reaction mixture was allowed to cool to ambient temperature. The nanoparticles were thoroughly washed before supporting them on carbon powder (Vulcan XC-72, Cabot) as described elsewhere [35]. Thermal treatments were done at low temperatures $\left(150,200\right.$, and $\left.300{ }^{\circ} \mathrm{C}\right)$ under pure hydrogen flow during $30 \mathrm{~min}$. These rather mild conditions were chosen to minimize particle growth while portions of the same sample of as-prepared catalyst were heat treated so the overall composition was the same. For all catalysts, the metal loading was $20 \mathrm{wt} . \%$. A Pt/C commercial catalyst (20 wt.\%, E-TEK) was used as reference sample. All chemicals (Aldrich) were used as received.

Samples were characterized by X-ray diffraction (XRD) using a Rigaku, model D Max2500 PC diffractometer. Scans were done at $1 \mathrm{~min}^{-1}$ for $2 \theta$ values between 15 and $100^{\circ}$ using $\mathrm{Cu} \mathrm{K} \alpha$ radiation $(\lambda=1.5406 \AA)$. Transmission electronic microscopy studies were carried out using a Philips CM 200 microscope operating at $200 \mathrm{kV}$. In situ dispersive X-ray absorption spectroscopy (DXAS) experiments around the $\mathrm{Pt}_{3}$ edge $(11,564.25 \mathrm{eV})$ were performed at the DXAS beam line of the Brazilian Synchrotron Light Laboratory (LNLS) [36]. The operation conditions were similar to those reported elsewhere [37]. The catalysts were used in the form of pellets with $6 \mathrm{mg} \mathrm{cm}^{-2} \mathrm{Pt}$ loading. The measurements were taken in a spectroelectrochemical cell at constant applied potential in $0.5 \mathrm{~mol} \mathrm{~L}^{-1} \mathrm{H}_{2} \mathrm{SO}_{4}$ solution.

Electrochemical measurements were made in a conventional electrochemical cell, with a Pt wire counter-electrode placed in a separate compartment and a reversible hydrogen reference electrode. The catalysts were used as ultra-thin layers (metal loading of $28 \mu \mathrm{g} \mathrm{cm}^{-2}$ ) on a previously polished glassy carbon disk electrode $\left(0.196 \mathrm{~cm}^{2}\right)$. Cyclic voltammetry (CV) experiments were carried out in Ar purged $0.5 \mathrm{~mol} \mathrm{~L}^{-1}$ $\mathrm{H}_{2} \mathrm{SO}_{4}$ solution while studies of the electrocatalytic activity for the ORR were performed in $\mathrm{O}_{2}$-saturated solution using the rotating disk electrode (RDE) technique. Solutions were prepared from analytical grade $\mathrm{H}_{2} \mathrm{SO}_{4}$ (Mallinckrodt), analytical grade methanol (Mallinckrodt), and ultra-pure water (MilliQ, Millipore). Methanol tolerance was assessed by measuring the ORR polarization curves in $\mathrm{O}_{2}$-saturated $0.5 \mathrm{~mol} \mathrm{~L}^{-1} \mathrm{H}_{2} \mathrm{SO}_{4}$ solution containing $0.1 \mathrm{~mol} \mathrm{~L}^{-1}$ methanol. All experiments were carried out at $25^{\circ} \mathrm{C}$.

\section{Results and discussion}

\section{As-prepared PtV/C}

The X-ray diffraction pattern for the as-prepared $\mathrm{PtV} / \mathrm{C}$ is presented in Fig. 1, where the pattern for $\mathrm{Pt} / \mathrm{C}$ is included for comparison. The diffractogram of the $\mathrm{PtV} / \mathrm{C}$ sample shows peaks at $2 \theta$ values around $40,46,67$, and $81^{\circ}$ typical of the face-centered cubic (fcc) Pt structure (PDF 4-802), as well as a wide signal at $25^{\circ}$ characteristic of the [002] planes of graphitic carbon. The mean crystallite size was estimate by Scherrer's 


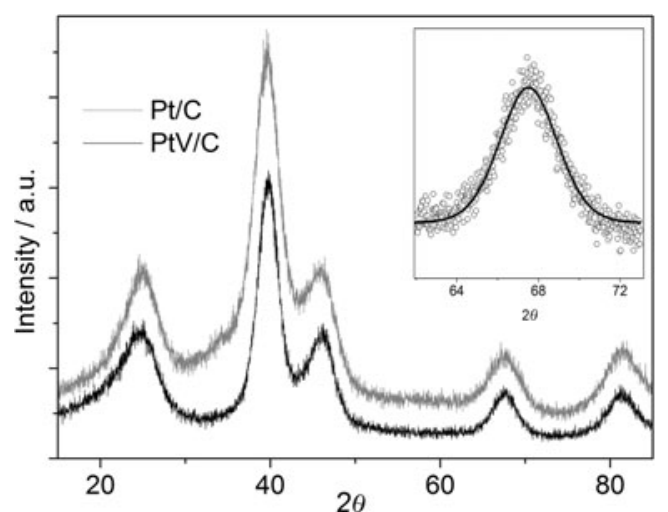

Fig. 1 XRD patterns for as-prepared $\mathrm{PtV} / \mathrm{C}$ and commercial $\mathrm{Pt} / \mathrm{C}$ catalysts. Inset: Pseudo-Voigt fitting of the [220] diffraction peak for the PtV/ C catalyst

equation using the [220] diffraction peak and found to be 2.8 and $2.5 \mathrm{~nm}$ for $\mathrm{PtV} / \mathrm{C}$ and $\mathrm{Pt} / \mathrm{C}$, respectively. For $\mathrm{PtV} / \mathrm{C}$, diffraction peaks are slightly shifted towards higher values of $2 \theta$ compared to those of $\mathrm{Pt} / \mathrm{C}$. Because partial substitution of $\mathrm{Pt}$ by atoms of smaller radii produces a contraction of the lattice, the shift in peak position can be taken as evidence of the formation of a PtV alloy. The lattice parameters were estimated from the [220] diffraction signal and were found to be $3.927 \AA \mathrm{for} \mathrm{Pt} / \mathrm{C}$, in good agreement with literature values [38] and $3.917 \AA$ for the PtV/C catalyst, i.e., only slightly smaller than for $\mathrm{Pt} / \mathrm{C}$.

The atomic fraction of a second metal $(M)$ in an alloyed phase can be estimated from Vegard's law:

$x_{M}=\frac{a-a_{o}}{a_{M}-a_{o}}$

where $a$ is the experimental value of the lattice parameter of the bimetallic alloy, $a_{o}$ is the lattice parameter of the base metal, and $a_{M}$ is the lattice constant of the second metal. Eq. (1) implies that both pure metals and the alloy have the same crystal structure. In many cases, the second metal does not have a cubic structure as $\mathrm{Pt}$, and then it is more convenient to take a PtM solid solution as reference material. Then, the atomic fraction of second metal in that alloy $(\alpha)$ must be introduced in Eq. (1) as correction factor:

$x_{M}=\alpha \frac{a-a_{o}}{a_{\text {alloy }}-a_{o}}$

The amount of vanadium in the alloyed phase was calculated from the lattice parameter obtained for $\mathrm{PtV} / \mathrm{C}(a)$, with $a_{o}=3.927 \AA, a_{\mathrm{allloy}}=3.90 \AA$ for the $\mathrm{PtV}$ solid solution of composition $90: 10[39,40]$ and $\alpha=0.1$, and it was found to be $4.5 \%$ (in atoms). According to the data for the $\mathrm{PtV}$ system published by Waterstrat [39] and later confirmed by Okamoto [40], a lattice parameter of $3.917 \AA$ corresponds to an alloy containing about $5 \%$ of vanadium atoms. The small amount of alloyed vanadium indicates that it is mostly in the form of oxides.
TEM studies revealed that PtV nanoparticles were homogeneuosly distributed on the carbon support. A typical micorgraph and the particle size histogram are shown in Fig. 2. The mean particle diameter was $3.7 \pm 0.3 \mathrm{~nm}$ while the narrow particle size distribution indicates that $\mathrm{PtV}$ nanoparticles were monodispersed $(\sigma<10 \%)$ [41]. For the $20 \%$ $\mathrm{Pt} / \mathrm{C}$ commercial catalyst used as reference particle size distribution was wider and centered about $3.5 \mathrm{~nm}$, in agreement with previously reported data [42].

Cyclic voltammetry curves shown in Fig. 3 evidence that the charge of oxidation of adsorbed hydrogen is significantly smaller for the $\mathrm{PtV} / \mathrm{C}$ catalyst than for the $\mathrm{Pt} / \mathrm{C}$ material. The small charge involved in the $\mathrm{CV}$ curve of $\mathrm{PtV} / \mathrm{C}$ is likely to be due to the presence of vanadium atoms on the surface in the form of a PtV-alloyed phase as well as to segregated amorphous vanadium oxides. Nevertheless, the $\mathrm{CV}$ curve for $\mathrm{PtV} /$ C prepared in this study (Fig. 3) has similar shape and charges as compared to those published for a catalyst prepared in a similar manner (Supporting Information of [6]). Because no contribution of vanadium or its oxides to the faradaic current should be expected in the potential region of hydrogen adsorption/desorption [43, 44], the Pt surface area can be estimated from the charge of oxidation of UPD hydrogen, after accounting for the double-layer charging and assuming, as usual, that a monolayer involves a charge of $0.210 \mathrm{mC} / \mathrm{cm}^{2}$ [45]. The Pt surface area values found were $24.8 \mathrm{~cm}^{2} / \mathrm{mg}_{\mathrm{Pt}}$ for $\mathrm{PtV} / \mathrm{C}$ and $75.7 \mathrm{~cm}^{2} / \mathrm{mg}_{\mathrm{Pt}}$ for the commercial Pt/C sample.

Figure 4a depicts a typical ORR polarization curve for asprepared $\mathrm{PtV} / \mathrm{C}$ catalyst compared with that of $\mathrm{Pt} / \mathrm{C}$, where current densities are normalized to the geometric area of the glassy carbon disk substrate. Masa et al. [46] have recently modeled the behavior of a RDE with its surface modified by nanoparticles and demonstrated that the polarization curves for two materials with the same intrinsic activity will show different half-wave potential $\left(E_{1 / 2}\right)$ if they have different electroactive surface areas. Moreover, $E_{1 / 2}$ will be more positive for the material with the higher area. Thus, it should be noted that the two curves of Fig. 4a are quite similar despite the significantly lower electroactive $\mathrm{Pt}$ area of the $\mathrm{PtV} / \mathrm{C}$ material, indicating that this catalyst has a significantly higher ORR activity. The kinetically controlled current $\left(i_{\mathrm{k}}\right)$ was calculated using the Koutecky-Levich equation:

$\frac{1}{i}=\frac{1}{i_{\mathrm{k}}}+\frac{1}{i_{\mathrm{L}}}$

where $i$ is the current measured in the polarization curve and $i_{\mathrm{L}}$ is diffusion limited current. To obtain the specific activity, $i_{\mathrm{k}}$ values were normalized by the Pt electrochemically active area of the catalyst that was estimated by the integration of adsorbed hydrogen oxidation charges, after correcting for double-layer charging. A comparison of specific activity for $\mathrm{PtV} / \mathrm{C}$ and $\mathrm{Pt} / \mathrm{C}$ at 0.90 and $0.85 \mathrm{~V}$ is shown in Fig. $4 \mathrm{~b}$, 
Fig. 2 TEM image and particle size distribution for $\mathrm{PtV} / \mathrm{C}$
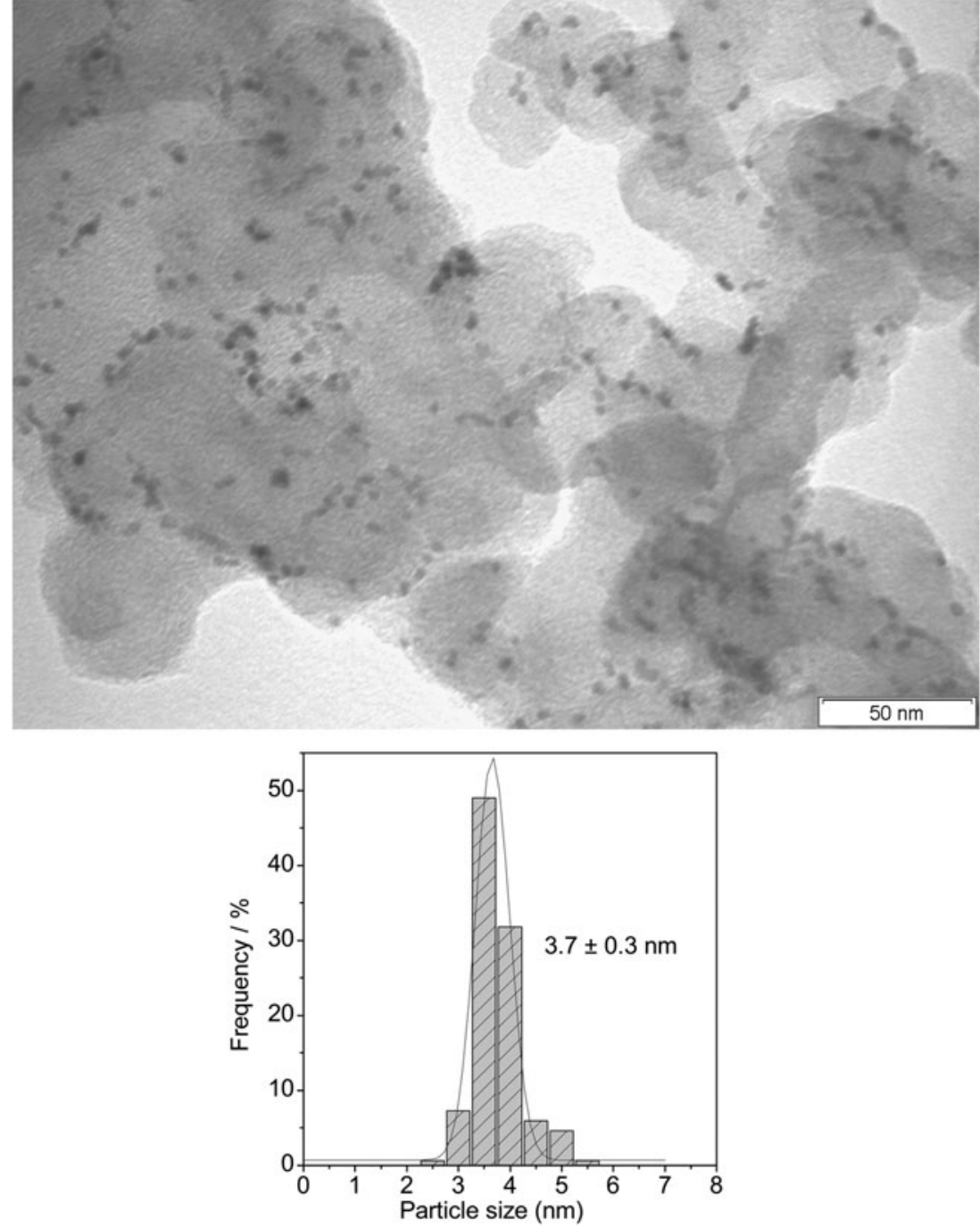

the literature [6]. Figure $4 \mathrm{c}$ shows a plot of mass activity at 0.85 and $0.90 \mathrm{~V}$. The mass transfer-corrected Tafel plot for ORR on PtV/C (not shown) exhibited distinct regions with slopes of -60 and $-120 \mathrm{mV} \mathrm{dec}{ }^{-1}$, as usually observed for Pt [47] and Pt-based catalysts [48].

So far, there is no consensus regarding the origin of the enhanced activity of Pt alloys. In some cases, interpretations considered mainly structural properties, such as the Pt-Pt nearest-neighbor distance [15] or the presence of a Pt skin [16]. In other cases, electronic properties were invoked to interpret an ORR enhanced activity, while explanations were given in terms of a larger Pt d-band vacancy [16] as well as based on a lower one [29, 8]. In the former case, it was argued that an enhanced ORR activity would be promoted by a stronger interaction of adsorbed $\mathrm{O}_{2}$ with $\mathrm{Pt}$ which would make the $\mathrm{O}-\mathrm{O}$ bond breaking easier [16]. In contrast, the effect of a larger occupancy of the Pt 5d-band was interpreted as beneficial for the ORR considering that it would weaken adsorption of oxygenated intermediate species produced after the breaking of the $\mathrm{O}_{2}$ molecule $[29,8]$. 
Fig. 4 a ORR polarization curves obtained in $\mathrm{O}_{2}$-saturated $0.5 \mathrm{~mol} \mathrm{~L}^{-1} \mathrm{H}_{2} \mathrm{SO}_{4}$ acid solution. Currents normalized by RDE geometric area $\left(0.196 \mathrm{~cm}^{2}\right)$. $\omega=2500 \mathrm{rpm} ; v=5 \mathrm{mV} \mathrm{s}^{-1}$; $T=25^{\circ} \mathrm{C}$. $\mathbf{b}$ Comparison of ORR-specific activities (currents normalized by Pt surface area) at 0.90 and 0.85 V. Gray bars for $\mathrm{PtV} / \mathrm{C}$ and white bars for $\mathrm{Pt} / \mathrm{C}$. c Comparison of ORR mass activities at 0.90 and $0.85 \mathrm{~V}$
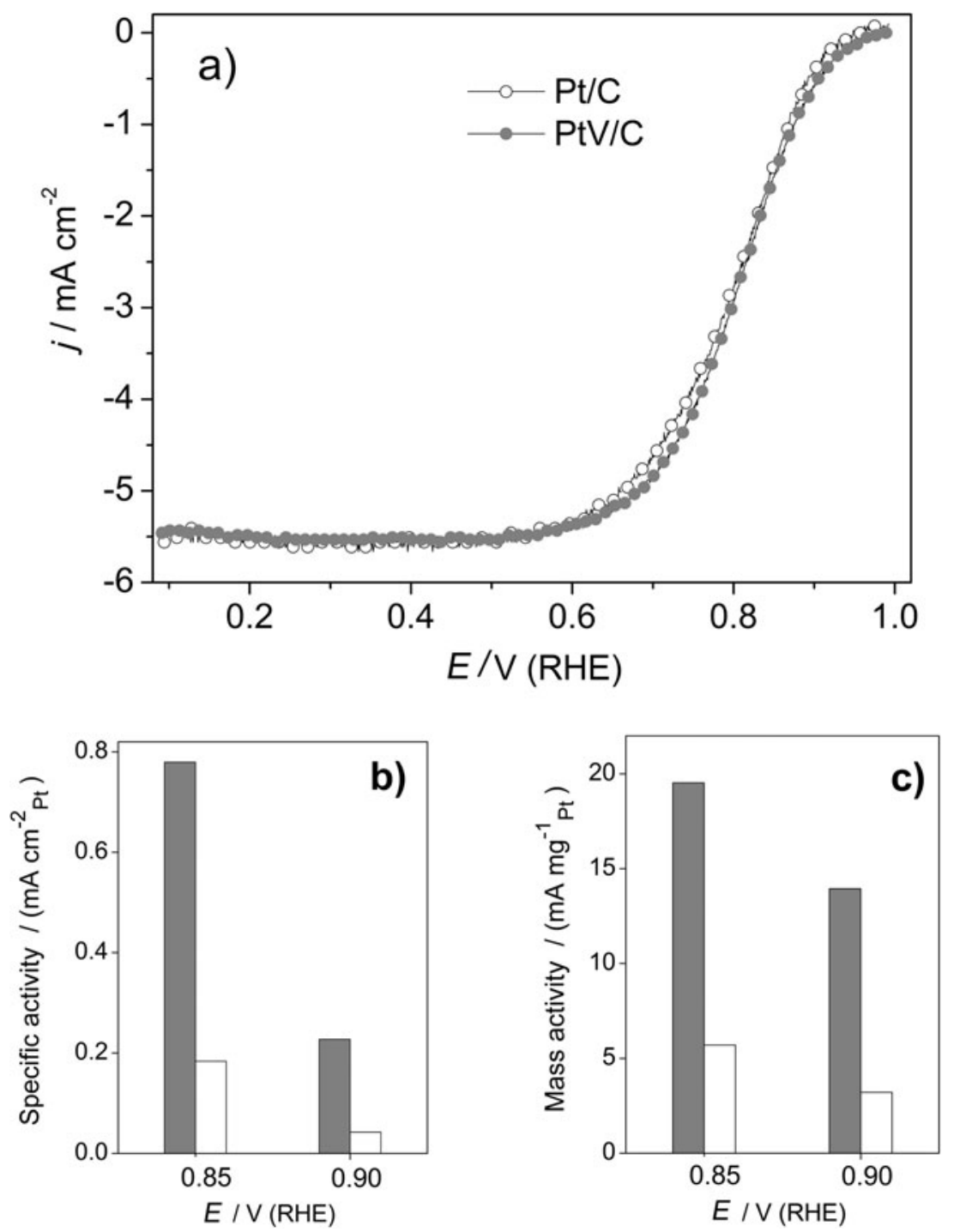

In order to get further insight on the catalyst properties relevant to ORR electrocatalysis, the electronic characteristics were determined in situ by dispersive X-ray absorption spectroscopy (DXAS) experiments carried out around the $\mathrm{Pt} \mathrm{L}_{3}$ edge $(11,564.25 \mathrm{eV})$. Figure 5a shows the normalized absorption spectra obtained at different applied potentials for $\mathrm{PtV} / \mathrm{C}$ in $0.5 \mathrm{~mol} \mathrm{~L}^{-1}$ sulfuric acid solution at $25^{\circ} \mathrm{C}$. Similar curves were obtained for $\mathrm{Pt} / \mathrm{C}$ (not shown). Data analysis was performed by using the method of Shukla et al. [49] to integrate the signal at the absorption edge (the so-called white line). The integrated intensity, which is proportional to the vacancy of the Pt 5d-band, is shown as function of the applied potential in Fig. 5b. The white line integrated intensity grows as the applied potential increases, which results from the adsorption of oxygenated species on the Pt surface [50]. In a general manner, DXAS data show that the integrated values are larger for $\mathrm{PtV} / \mathrm{C}$ than for the $\mathrm{Pt} / \mathrm{C}$ reference sample indicating that the presence of vanadium lead to an increase in the Pt 5d-band vacancy and that despite the rather low content of alloyed vanadium, the difference appears to be significant. This observation is in agreement with data reported for metals such as $\mathrm{Fe}, \mathrm{Co}$, and $\mathrm{Ni}[9,10,51]$ at the time that differs from the conclusions of Santos et al. for heat-treated commercial PtV/C catalysts [29].

Figure $5 \mathrm{~b}$ also shows that the rise of the integrated absorption signal with applied potential is less marked for $\mathrm{PtV} /$ $\mathrm{C}$ than for $\mathrm{Pt} / \mathrm{C}$. Keeping in mind that such a rise is attributed to adsorption of oxygenated species on the Pt surface [50], data suggest that the oxidation of $\mathrm{Pt}$ in the $\mathrm{PtV} / \mathrm{C}$ catalyst is less favored [17]. This is in agreement with theoretical calculations that indicate that the formation potential of adsorbed $\mathrm{OH}$ is significantly dependent on the subsurface composition [52]. According to literature, the blockage of surface sites by adsorbed $\mathrm{OH}$ species inhibits the ORR and therefore, a decrease in $\mathrm{OH}$ coverage would enhanced ORR activity [20]. 

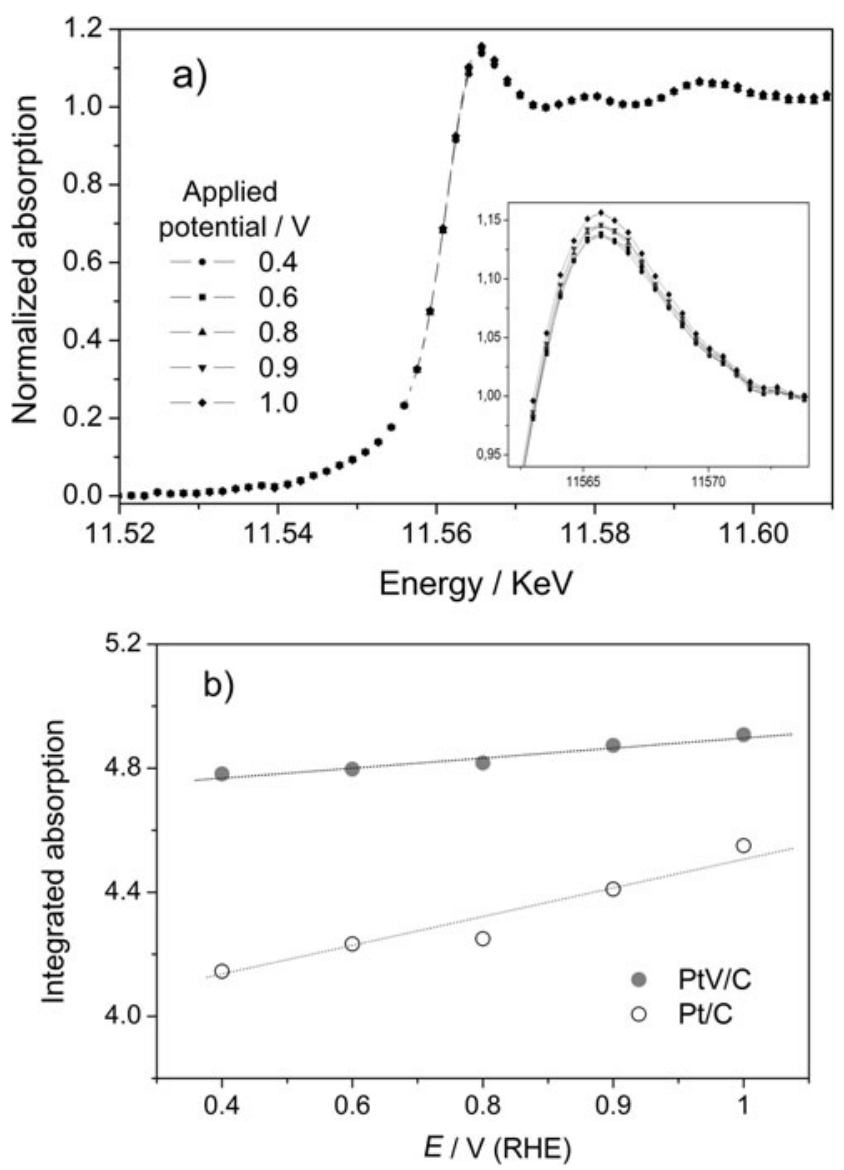

Fig. 5 a Normalized absorption at the $\mathrm{Pt} \mathrm{L}_{3}$ edge for $\mathrm{PtV} / \mathrm{C}$ at different applied potentials in $0.5 \mathrm{~mol} \mathrm{~L}^{-1} \mathrm{H}_{2} \mathrm{SO}_{4}$. b Comparison of integrated intensities as a function of applied potential

Altogether, data of Fig. 5 indicate clearly that the Pt 5dband vacancy is larger for the $\mathrm{PtV} / \mathrm{C}$ catalyst and, at the same time, suggest a reduced Pt coverage by adsorbed $\mathrm{OH}$ species. It is likely that both effects play a role on the ORR enhanced activity of the $\mathrm{PtV} / \mathrm{C}$ catalyst.

\section{Heat-treated PtV/C catalysts}

Portions of the as-prepared $\mathrm{PtV} / \mathrm{C}$ catalyst were treated in pure hydrogen atmosphere and at low temperatures $(150,200$, and $300{ }^{\circ} \mathrm{C}$ ) in a tubular furnace. For the sake of simplicity, the samples will be referred to as PtV/C-150, PtV/C-200, and $\mathrm{PtV} / \mathrm{C}-300$.

TEM analysis revealed a moderate growth of the catalysts nanoparticles that remained homogeneously distributed on the carbon support. TEM images and histograms of particle size distribution are shown in Fig. 6. In general, particle growth is commonly observed when Pt alloys are heat-treated although its extent is largely dependent on treatment temperature and time $[37,29,30,9]$.
XRD studies showed diffraction patterns similar to those of Fig. 1, with small variations in the average crystallite size and slight changes in peak position. Table 1 summarizes the structural parameters calculated from XRD data. As it can be seen, for all heat-treated samples, the amount of alloyed vanadium is larger than for as-prepared PtV/C. It should be noted, however, that the largest incorporation of vanadium in the alloyed phase is observed for the $\mathrm{PtV} / \mathrm{C}-150$ catalyst while it decreases for higher treatment temperatures.

Electrochemical characterization by cyclic voltammetry evidenced variations of charge in hydrogen adsorption/ dessorption region (Fig. 7), indicating that heat treatment promoted some Pt segregation to the nanoparticles surface. The increase of $\mathrm{Pt}$ electrochemically active area was larger for treatment at $150{ }^{\circ} \mathrm{C}$. For the PtV/C-300, a slight decrease in $\mathrm{Pt}$ active area was observed, most likely associated to particle growth.

Differences in ORR specific and mass activity were observed for these catalysts (Fig. 8), which are, in general, more active than Pt/C. The ORR studies carried out by Santos et al. [29] using a commercial catalyst showed the largest specific activity after heat treatment in $\mathrm{H}_{2}$ at $300{ }^{\circ} \mathrm{C}$, the lowest temperature used in their study. Studies done by Sasaki et al. [17] showed an enhancement of ORR activity for niobium oxide-supported platinum, which was attributed to a decreased $\mathrm{OH}$ adsorption on Pt resulting from lateral repulsion with oxide surface species. Thus, the possibility of vanadium oxides playing a relevant role in ORR catalysis should not be discarded.

Methanol tolerance was evaluated from RDE experiments done in $\mathrm{O}_{2}$-saturated acid solutions containing $0.1 \mathrm{~mol} \mathrm{~L}^{-1}$ methanol. A comparison of currents measured at $0.85 \mathrm{~V}$ in the absence and in the presence of the alcohol is shown in Fig. 9. For $\mathrm{PtV} / \mathrm{C}$, the current measured at $0.85 \mathrm{~V}$ in methanol-containing solution drops to about $32 \%$ of its value in methanol-free environment. As it can be seen, current losses are larger for heat-treated catalysts. It should be mentioned that despite the considerable loss of current due to the presence of the alcohol, PtV materials showed superior methanol tolerance than $\mathrm{Pt} / \mathrm{C}$.

\section{Effect of the reducing environment on the amount on alloyed vanadium}

The results presented above indicate that low-temperature treatments in a pure $\mathrm{H}_{2}$ atmosphere promoted an increase in the incorporation of vanadium into the Pt lattice comparison with the as-prepared material. However, as shown in Table 1, that increase in alloying decreases for increasing treatment temperature. Analysis of data reported in the literature for heat-treated commercial $\mathrm{PtV} / \mathrm{C}$ revealed the lack of clear trends. On one hand, different values of lattice parameter for as-received commercial $\mathrm{PtV} / \mathrm{C}$ catalyst were 
Fig. 6 TEM images and particle size distributions for PtV-150 (a), PtV-200 (b), and PtV-300 (c)
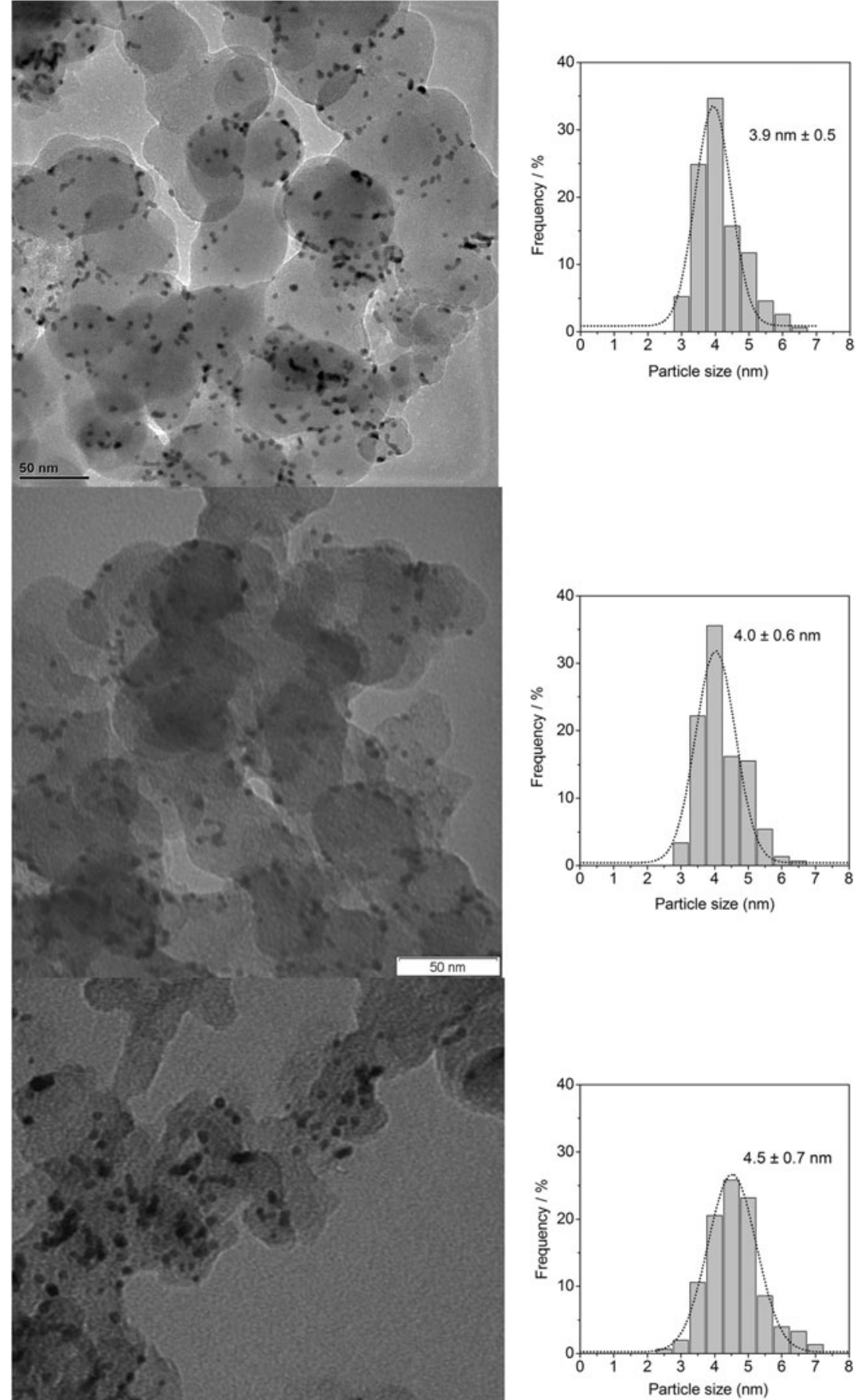

reported $[29,30]$, despite the fact that nominal composition and supplier were the same. For treatments in pure $\mathrm{H}_{2}$, a decrease in the lattice constant was reported for catalysts heated at 500 and $850{ }^{\circ} \mathrm{C}$ [30], while larger values that indicated a decrease in the content of alloyed vanadium were found for the commercial $\mathrm{PtV} / \mathrm{C}$ catalyst heat-treated at 300,500 , and $850{ }^{\circ} \mathrm{C}$ [29].
Seeking further understanding of the structural changes taking place below $300{ }^{\circ} \mathrm{C}$, some experiments were carried out at the D10-XPD beam line of the Brazilian Synchrotron Light Laboratory (LNLS). The sample was placed inside a furnace under a flow of $10 \mathrm{~mL} \mathrm{~min}^{-1}$ of $5 \% \mathrm{H}_{2} / \mathrm{He}$ mixture, and diffraction patterns were collected either as a function of time at constant temperature or as a function of temperature 
Table 1 Structural parameters calculated from XRD data

\begin{tabular}{llll}
\hline Catalyst & Lattice constant $(\AA)$ & Crystallite size $(\mathrm{nm})$ & V in the alloyed phase (at.\%) \\
\hline $\mathrm{Pt} / \mathrm{C}$ & 3.927 & 2.5 & - \\
$\mathrm{PtV} / \mathrm{C}$ & 3.917 & 2.8 & 4.5 \\
$\mathrm{PtV} / \mathrm{C}-150$ & 3.913 & 3.2 & 5.7 \\
$\mathrm{PtV} / \mathrm{C}-200$ & 3.914 & 3.1 & 5.2 \\
$\mathrm{PtV} / \mathrm{C}-300$ & 3.915 & 4.5 & 4.9 \\
\hline
\end{tabular}

during the heating ramp $\left(2^{\circ} \mathrm{C} / \mathrm{min}\right)$. To follow better the changes, $2 \theta$ scans were restricted to the region of the $\mathrm{Pt}$ [220] signal. Diffraction patterns collected at constant temperature (i.e., after reaching the values of 150,200 , and $300{ }^{\circ} \mathrm{C}$ ) did not change with time, indicating that structural changes took place during the heating ramp. For all three heating temperatures, a shift towards lower $2 \theta$ values was observed evidencing a decrease of the alloyed vanadium amount with respect of the as-prepared catalyst. The gradual shift of peak position towards lower $2 \theta$ values was more clearly observed when diffraction patterns were collected during the heating ramp $\left(2{ }^{\circ} \mathrm{C} / \mathrm{min}\right)$, as shown in Fig. 10. These experiments revealed that structural variations of $\mathrm{PtV}$ nanoparticles are not solely dependent on the temperature of treatment as they also depend on the strength of the reducing atmosphere. While heating under mild reducing conditions ( $5 \% \mathrm{H}_{2} / \mathrm{He}$ mixture) appear to promote a gradual dealloying of vanadium (Fig. 10), under pure $\mathrm{H}_{2}$ atmosphere, the amount of alloyed vanadium was found to be larger than for untreated $\mathrm{PtV} / \mathrm{C}$ (Table 1) for all three heating temperatures $\left(150,200\right.$, and $\left.300{ }^{\circ} \mathrm{C}\right)$.

The phase diagram of the PtV system [39, 40] is quite complex but shows clearly that a $\mathrm{Pt}$ phase is stable over a wide composition region (from 0 to ca. $50 \% \mathrm{~V}$ ). In turn, depending on composition and temperature Pt could coexist with stable $\mathrm{Pt}_{3} \mathrm{~V}$ and $\mathrm{Pt}_{2} \mathrm{~V}$ phases as well as with a metastable $\mathrm{Pt}_{8} \mathrm{~V}$. Even though the lowest temperature in

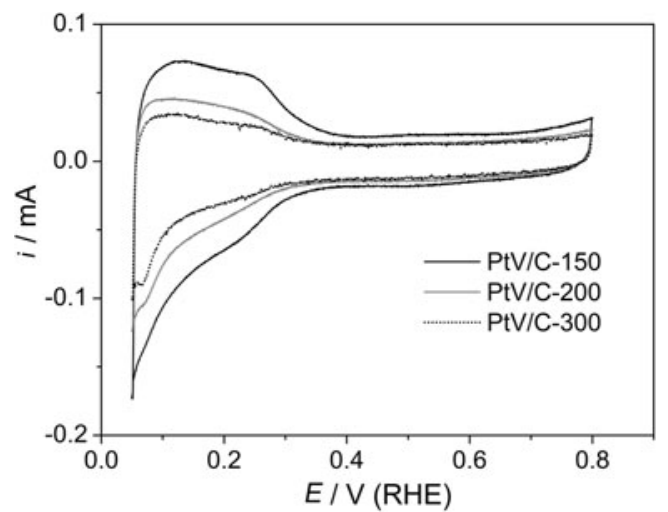

Fig. 7 Cyclic voltammetry curves obtained in $0.5 \mathrm{~mol} \mathrm{~L}^{-1} \mathrm{H}_{2} \mathrm{SO}_{4}$ acid solution for catalysts heat-treated in pure $\mathrm{H}_{2} . v=50 \mathrm{mV} \mathrm{s}^{-1} ; T=25^{\circ} \mathrm{C}$ published phase diagrams is $400{ }^{\circ} \mathrm{C}[39,40]$, the observed changes can be interpreted assuming that phases and bicontinuous regions are similar at lower temperatures. Then, the gradual vanadium segregation that took place during heating in $5 \% \mathrm{H}_{2} / \mathrm{He}$ mixture should come to not surprise because according to the phase diagram, the $\mathrm{Pt}$ phase is stable in the region of low vanadium content (c.a. below $10 \% \mathrm{~V}$ ). On the other hand, treatment in pure $\mathrm{H}_{2}$ would result in a larger and localized availability of metallic vanadium due to the reduction of oxides, leading to vanadium incorporation into the $\mathrm{Pt}$ lattice. Comparison of data obtained in this work with literature [29, 30] allows rationalizing the different effects of heat treatments, which clearly depend on the strength of the reducing environment
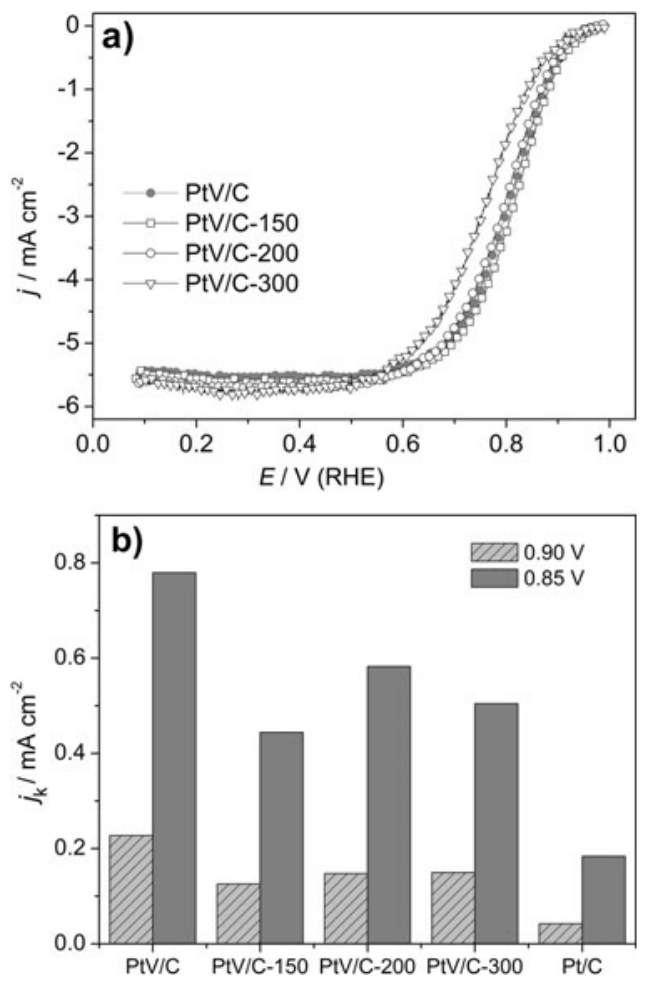

Fig. 8 a ORR polarization curves obtained in $\mathrm{O}_{2}$-saturated $0.5 \mathrm{~mol} \mathrm{~L}^{-1}$ $\mathrm{H}_{2} \mathrm{SO}_{4}$ acid solution. Currents normalized by RDE geometric area. $\omega=2500 \mathrm{rpm} ; v=5 \mathrm{mV} \mathrm{s}^{-1} ; T=25{ }^{\circ} \mathrm{C}$. b Comparison of ORR intrinsic activities (currents normalized by Pt surface area) at 0.90 and $0.85 \mathrm{~V}$ 


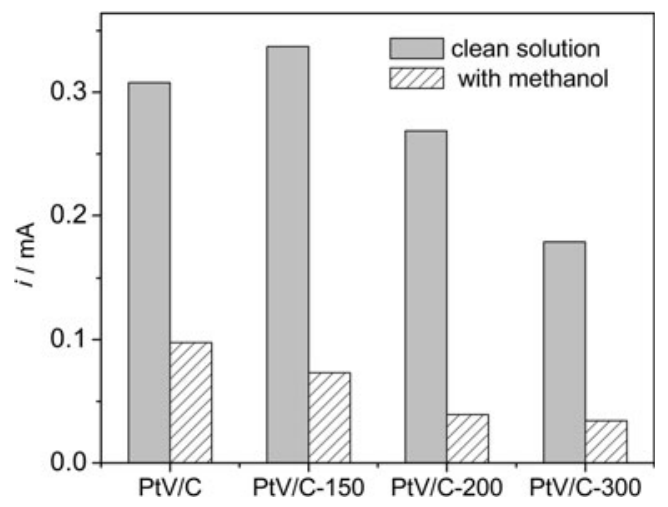

Fig. 9 Comparison of currents measured at $0.85 \mathrm{~V}$ in $\mathrm{O}_{2}$-saturated $0.5 \mathrm{~mol} \mathrm{~L}^{-1} \mathrm{H}_{2} \mathrm{SO}_{4}$ with and without $0.1 \mathrm{~mol} \mathrm{~L}^{-1}$ methanol. $\omega=2500 \mathrm{rpm} ; v=5 \mathrm{mV} \mathrm{s}^{-1} ; T=25^{\circ} \mathrm{C}$

and temperature as well as on the amount of metallic and oxide vanadium initially present. The interplay of two effects (tendency to segregation and an increased availability of metallic vanadium) would also explain the increase in the amount of alloyed vanadium (Table 1) as well as the Pt enrichment of the surface apparent in the curves of Fig. 7 for materials heat treated in pure $\mathrm{H}_{2}$.

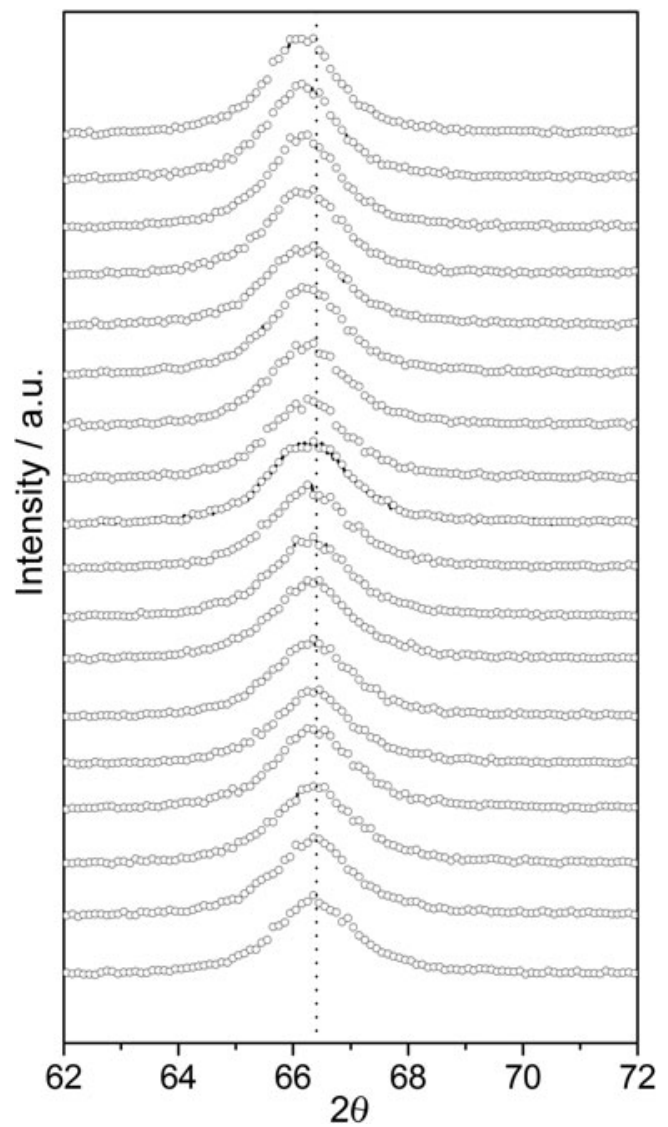

Fig. 10 High-resolution XRD of Pt [220] planes for PtV/C at different times during the heating ramp from ambient temperature to $300{ }^{\circ} \mathrm{C}$ heating in $5 \% \mathrm{H}_{2} / \mathrm{He}$. Diffraction patterns for temperature increasing from bottom to top

\section{Conclusions}

This study showed that carbon-supported PtV nanoparticles prepared by a polyol method have low content of alloyed vanadium and that ORR activity and methanol tolerance are substantially superior to $\mathrm{Pt} / \mathrm{C}$. Studies of the electronic properties indicated that the presence of vanadium promoted an increase in the Pt 5d-band vacancy and a reduction on coverage of adsorbed $\mathrm{OH}$ species. It is likely that both effects play a role on the enhanced ORR activity of PtV/C. Heat treatments up to $300{ }^{\circ} \mathrm{C}$ in strongly reducing environment (pure $\mathrm{H}_{2}$ ) produced a slight increase in the amount of alloyed vanadium and Pt enrichment of the surface and were detrimental for ORR activity and methanol tolerance. Dealloying observed for catalyst heated under mild reducing conditions $\left(5 \% \mathrm{H}_{2} /\right.$ He mixture) demonstrated that, in the composition region of this study, the structural changes produced by lowtemperature heat treatments are different depending on the strength of the reducing environment.

Acknowledgments Thanks are due to São Paulo Research Foundation (FAPESP) (2011/06538-7, 2014/12255-6) and National Council for Scientific and Technological Development (CNPq) (407143/2013-0) for financial support and to the Brazilian Synchrotron Light Laboratory (LNLS) for assisting DXAS and XRD measurements.

\section{References}

1. Srinivasan S (2006) Fuel cells: from fundamentals to applications, 1 st edn. Springer, New York

2. Alonso-Vante N (2010) Platinum and Non-platinum nanomaterials for the molecular oxygen reduction reaction. ChemPhysChem 11: 2732-2744

3. Pires FI, Villullas HM (2012) Pd-based catalysts: influence of the second metal on their stability and oxygen reduction activity. Int $\mathrm{J}$ Hydrogen Energ 37:17052-17059

4. Antolini E, Salgado JRC, Gonzalez ER (2005) Carbon supported Pt75M25 (M = Co, Ni) alloys as anode and cathode electrocatalysts for direct methanol fuel cells. J Electroanal Chem 580:145-154

5. Antolini E, Salgado JRC, Santos LGRA, Garcia G, Ticianelli EA, Pastor E, Gonzalez ER (2006) Carbon supported Pt-Cr alloys as oxygen-reduction catalysts for direct methanol fuel cells. J Appl Electrochem 36:355-362

6. Yano H, Kataoka M, Yamashita H, Uchida H, Watanabe M (2007) Oxygen reduction activity of carbon-supported Pt-M (M $=\mathrm{V}, \mathrm{Ni}$, $\mathrm{Cr}, \mathrm{Co}$, and $\mathrm{Fe}$ ) alloys prepared by nanocapsule method. Langmuir 23:6438-6445

7. Xiong L, Manthiram A (2005) Nanostructured Pt-M/C (M = Fe and Co) catalysts prepared by a microemulsion method for oxygen reduction in proton exchange membrane fuel cells. Electrochim Acta 50:2323-2329

8. Antolini E, Salgado JRC, Giz MJ, Gonzalez ER (2005) Effects of geometric and electronic factors on ORR activity of carbon supported Pt-Co electrocatalysts in PEM fuel cells. Int J Hydrogen Energ 30:1213-1220

9. Malheiro AR, Perez J, Santiago EI, Villullas HM (2010) The extent on the nanoscale of Pt-skin effects on oxygen reduction and its influence on fuel cell power. J Phys Chem C 114:20267-20271 
10. Malheiro AR, Perez J, Villullas HM (2010) Dependence on composition of electronic properties and stability of $\mathrm{Pt}-\mathrm{Fe} / \mathrm{C}$ catalysts for oxygen reduction. J Power Sources 195:7255-72586

11. Stassi A, D'Urso C, Baglio V, Di Blasi A, Antonucci V, Arico AS, Luna AMC, Bonesi A, Triaca WE (2006) Electrocatalytic behaviour for oxygen reduction reaction of small nanostructured crystalline bimetallic Pt-M supported catalysts. J Appl Electrochem 36: 1143-1149

12. Carbonio EA, Colmati F, Ciapina EG, Pereira ME, Gonzalez ER (2010) $\mathrm{Pt}-\mathrm{Cu} / \mathrm{C}$ and $\mathrm{Pd}$ modified $\mathrm{Pt}-\mathrm{Cu} / \mathrm{C}$ electrocatalysts for the oxygen reduction reaction in direct methanol fuel cells. J Brazil Chem Soc 21:590-602

13. Baglio V, Stassi A, Di Blasi A, D'Urso C, Antonucci V, Arico AS (2007) Investigation of bimetallic Pt-M/C as DMFC cathode catalysts. Electrochim Acta 53:1360-1364

14. Bing Y, Liu H, Zhang L, Ghosh D, Zhang J (2010) Nanostructured Pt-alloy electrocatalysts for PEM fuel cell oxygen reduction reaction. Chem Soc Rev 39:2184-2202

15. Jalan V, Taylor EJ (1983) Importance of interatomic spacing in catalytic reduction of oxygen in phosphoric-acid. J Electrochem Soc 130:2299-2301

16. Toda T, Igarashi H, Uchida H, Watanabe M (1999) Enhancement of the electroreduction of oxygen on $\mathrm{Pt}$ alloys with $\mathrm{Fe}, \mathrm{Ni}$, and $\mathrm{Co} . \mathrm{J}$ Electrochem Soc 146:3750-3756

17. Sasaki K, Zhang L, Adzic RR (2008) Niobium oxide-supported platinum ultra-low amount electrocatalysts for oxygen reduction. Phys Chem Chem Phys 10:159-167

18. Stephens IEL, Bondarenko AS, Gronbjerg U, Rossmeisl J, Chorkendorff I (2012) Understanding the electrocatalysis of oxygen reduction on platinum and its alloys. Energy Environ Sci 5((5)):6744-6762

19. Wang Y-J, Zhao N, Fang B, Li H, Bi XT, Wang H (2015) Carbonsupported Pt-based alloy electrocatalysts for the oxygen reduction reaction in polymer electrolyte membrane fuel cells: particle size, shape, and composition manipulation and their impact to activity. Chem Rev 115(9):3433-3467

20. Stamenkovic VR, Mun BS, Arenz M, Mayrhofer KJJ, Lucas CA, Wang GF, Ross PN, Markovic NM (2007) Trends in electrocatalysis on extended and nanoscale Pt-bimetallic alloy surfaces. Nat Mater 6(3):241-247

21. Norskov JK, Rossmeisl J, Logadottir A, Lindqvist L, Kitchin JR, Bligaard T, Jonsson H (2004) Origin of the overpotential for oxygen reduction at a fuel-cell cathode. J Phys Chem B 108(46):17886-17892

22. Antolini E, Lopes T, Gonzalez ER (2008) An overview of platinum-based catalysts as methanol-resistant oxygen reduction materials for direct methanol fuel cells. J Alloy Compd 461: 253-262

23. Kim KT, Kim YG, Chung JS (1995) Effect of surface roughening on the catalytic activity of Pt-Cr electrocatalysts for the oxygen reduction in phosphoric-acid fuel-cell. J Electrochem Soc 142: $1531-1538$

24. Yang H, Alonso-Vante N, Lamy C, Akins DL (2005) High methanol tolerance of carbon-supported $\mathrm{Pt}-\mathrm{Cr}$ alloy nanoparticle electrocatalysts for oxygen reduction. J Electrochem Soc 152: A704-A709

25. Yang H, Alonso-Vante N, Leger JM, Lamy C (2004) Tailoring, structure, and activity of carbon-supported nanosized Pt-Cr alloy electrocatalysts for oxygen reduction in pure and methanolcontaining electrolytes. J Phys Chem B 108:1938-1947

26. Lima FHB, Giz MJ, Ticianelli EA (2005) Electrochemical performance of dispersed Pt-M ( $\mathrm{M}=\mathrm{V}, \mathrm{Cr}$ and $\mathrm{Co})$ nanoparticles for the oxygen reduction electrocatalysis. J Brazil Chem Soc 16:328-336

27. Koffi RC, Coutanceau C, Garnier E, Leger JM, Lamy C (2005) Synthesis, characterization and electrocatalytic behaviour of nonalloyed PtCr methanol tolerant nanoelectrocatalysts for the oxygen reduction reaction (ORR). Electrochim Acta 50:4117-4127
28. Escano MC, Gyenge E, Nakanishi H, Kasai H (2011) Pt/Cr and Pt/ $\mathrm{Ni}$ catalysts for oxygen reduction reaction: to alloy or not to alloy? J Nanosci Nanotechnol 11:2944-2951

29. Santos LGRA, Freitas KS, Ticianelli EA (2009) Heat treatment effect of Pt-V/C and $\mathrm{Pt} / \mathrm{C}$ on the kinetics of the oxygen reduction reaction in acid media. Electrochim Acta 54:5246-5251

30. Antolini E, Passos RR, Ticianelli EA (2002) Electrocatalysis of oxygen reduction on a carbon supported platinum-vanadium alloy in polymer electrolyte fuel cells. Electrochim Acta 48:263-270

31. Antolini E (2003) Formation of carbon-supported PtM alloys for low temperature fuel cells: a review. Mater Chem and Phys 78:563-573

32. Zagudaeva NM, Tarasevich MR (2010) Electrochemical characteristics of platinum-based binary catalysts for middle-temperature hydrogen-air fuel cells with phosphoric acid electrolyte. Russ J Electrochem 46:530-536

33. Sung Y, Hwang J, Chung JS (2011) Characterization and activity correlations of Pt bimetallic catalysts for low temperature fuel cells. Int J Hydrogen Energ 36:4007-4014

34. Sun SH, Murray CB, Weller D, Folks L, Moser A (2000) Monodisperse FePt nanoparticles and ferromagnetic FePt nanocrystal superlattices. Science 287:1989-1992

35. Santiago EI, Varanda LC, Villullas HM (2007) Carbon-supported Pt-Co catalysts prepared by a modifled polyol process as cathodes for PEM fuel cells. J Phys Chem C 111:3146-3151

36. Tolentino HCN, Cezar JC, Watanabe N, Piamonteze C, Souza-Neto NM, Tamura E, Ramos A, Neueschwander R (2005) The dispersive X-ray absorption spectroscopy beamline at LNLS. Phys Scr T115: 977-979

37. Malheiro AR, Perez J, Villullas HM (2010) Surface structure and electronic properties of $\mathrm{Pt}-\mathrm{Fe} / \mathrm{C}$ nanocatalysts and their relation with catalytic activity for oxygen reduction. J Power Sources 195: 3111-3118

38. Beard BC, Ross PN (1990) The structure and activity of Pt-Co alloys as oxygen reduction electrocatalysts. J Electrochem Soc 137:3368-3374

39. Waterstrat RM (1973) Vanadium-platinum constitution diagram. Metall Trans 4:455-466

40. Okamoto H (2009) Pt-V (platinum-vanadium). J Phase Equilib Diff 30:666-667

41. Hunter RJ (1989) Foundations of colloid science, vol 1. Clarendon Press, Oxford

42. Lizcano-Valbuena WH, Paganin VA, Leite CAP, Galembeck F, Gonzalez ER (2003) Catalysts for DMFC: relation between morphology and electrochemical performance. Electrochim Acta 48: 3869-3878

43. Barrado E, Pardo R, Castrillejo Y, Vega M (1997) Electrochemical behaviour of vanadium compounds at a carbon paste electrode. $\mathrm{J}$ Electroanal Chem 427(1-2):35-42

44. Conway BE, Jerkiewicz G (2000) Relation of energies and coverages of underpotential and overpotential deposited $\mathrm{H}$ at $\mathrm{Pt}$ and other metals to the 'volcano curve' for cathodic H-2 evolution kinetics. Electrochim Acta 45(25-26):4075-4083

45. Trasatti S, Petrii OA (1991) Real surface-area measurements in electrochemistry. Pure Appl Chem 63(5):711-734

46. Masa J, Batchelor-McAuley C, Schuhmann W, Compton RG (2014) Koutecky-levich analysis applied to nanoparticle modified rotating disk electrodes: electrocatalysis or misinterpretation? Nano Res 7:71-78

47. Tarasevich MR, Sadkowski A, Yeager E (1983) Oxygen electrochemistry. In: Conway B, Bockris JM, Yeager E, Khan SM, White $\mathrm{R}$ (eds) Comprehensive Treatise of Electrochemistry. Springer US, pp 301-398

48. Malheiro AR, Perez J, Villullas HM (2009) Well-alloyed PtFe/C nanocatalysts of controlled composition and same particle size: oxygen reduction and methanol tolerance. J Electrochem Soc 156:B51-B58 
49. Shukla AK, Raman RK, Choudhury NA, Priolkar KR, Sarode PR, Emura S, Kumashiro R (2004) Carbon-supported Pt-Fe alloy as a methanol-resistant oxygen-reduction catalyst for direct methanol fuel cells. J Electroanal Chem 563:181-190

50. Hwang BJ, Tsai YW, Lee JF, Borthen P, Strehblow HH (2001) In situ EXAFS investigation of carbon-supported Pt clusters under potential control. J Synchrotron Radiat 8:484-48651
51. Mukerjee S, Srinivasan S, Soriaga MP, McBreen J (1995) Role of structural and electronic-properties of Pt and Pt alloys on electrocatalysis of oxygen reduction - an in-situ XANES and EXAFS investigation. J Electrochem Soc 142:1409-1422

52. Roques J, Anderson AB (2005) Cobalt concentration effect in Pt1$\mathrm{xCox}$ on the reversible potential for forming OHads from H2Oads in acid solution. Surf Sci 581(2-3):105-117 